\title{
Intervirology
}

Beggel, B. 232

Bertoletti, A. 158

Bonino, F. 163

Brunetto, M.R. 163

Filomia, R. 189

Gehring, A. 158

Geipel, A. 225

Gerlich, W.H. 131, 202

Glebe, D. 131, 134, 225

Gürtler, L.G. 131, 212
Kaiser, R. 131, 232

König, A. 134

Kramvis, A. 141

Lempp, F.A. 151

Locarnini, S. 218

Maimone, S. 189

Neumann-Fraune, M. 232

Obermeier, M. 232

Patel, K. 181
Raimondo, G. 189

Roche, B. 196

Samuel, D. 196

Tavis, J.E. 158

Tillmann, H.L. 181

Urban, S. 151

van Bömmel, F. 171

Warner, N. 218

\section{Subject Index Vol. 57, No. 3-4, 2014}

Acute hepatitis 181

Antiretroviral therapy 212

Antiviral resistance 218, 225

- therapy 134, 181, 196, 202

Bioinformatics 232

Chronic hepatitis B 163

- _ - treatment 163

Cirrhosis 196

Covalently closed circular DNA 134

Entecavir 202

Entry inhibition 151

Escape mutations 232

Fulminant liver failure 181

Genotypic testing 232

HBsAg quantification 163

Healthcare providers 202
Hepatitis B 181, 196, 202

- _ immune globulin 196

- - virus 134, 151, 158, 171, 181, 218, 225

- _ chronic carrier 202

- _ core antibody 189

- _ - DNA 163,202

- - - infectivity 202

- _ - resistance 232

- $\quad$ - $\quad$ surface antigen 189

HIV/hepatitis B virus coinfection 212

Immune response 163

Immunotherapy 158

Interferon 163

Interpretation system 232

Liver transplantation 196

Mechanisms of action 218

Mother-to-child transmission 202

Myrcludex B 151
NTCP 151

Nucleos(t)ide analogues 218

Nucleoside analogue 171

Nucleotide analogue 171

Occult hepatitis B virus infection 189

Pathogenesis 212

Phenotypic assays 225

Phylogenetic analysis 141

Replication 134

Serological subtype 141

Sodium-taurocholate cotransporting polypeptide 151

Subgenotype 141

Telbivudine 202

Tenofovir 202

Viral fitness 225

Virus entry 151 